\title{
UPAYA MENINGKATKAN RASA INGIN TAHU DAN PRESTASI BELAJAR BAHASA JAWA MATERI MENULIS AKSARA JAWA MELALUI METODE STRUKTURAL ANALITIK SINTETIK
}

\author{
Hening Setio Widiasih \\ SD Negeri 2 Kaligondang, Purbalingga, Indonesia \\ Email: heningsetiowidiasih@gmail.com
}

\begin{abstract}
The research is supported by the low curiosity and learning achievement of the students for the fifth graders SDN 2 Kaligondang. It aims: to improve the curiosity and learning achievement of Javanese Language on the topic of writing Javanese letters through synthetic analytic structural (SAS). The subject covered the fifth graders of SDN 2 Kaligondang consisted of 23 students. This classroom action research consisted of 2 cycles and each cycles had 2 meetings (per meeting included 2 teaching hours). The procedures included planning, acting, observing and reflecting. The data were collected by observation sheets of the teacher and students. The curiosity and learning achievement were gathered from test and questionnaire by the end of the cycle. The first cycle showed the mean of students' curiosity $28.51 \%$. The learning achievement in the first cycle was $60.86 \%$ with the mean 68.65. The second cycle showed that the mean of students' curiosity was 34.13. The learning achievement was $86.95 \%$ with the mean 80.47 . Thus, it could be drawn that Synthetic Analytic Structural could improve students' curiosity and learning achievement for the fifth graders SDN 2 Kaligondang
\end{abstract}

Keywords: curiosity, learning achievement, Javanese language, SAS method (Synthetic Analytics Structural)

Abstrak. Penelitian ini dilatarbelakangi oleh rendahnya rasa ingin tahu dan prestasi belajar siswa kelas V SD Negeri 2 Kaligondang. Tujuan penelitian: meningkatkan rasa ingin tahu dan prestasi belajar Bahasa Jawa materi menulis aksara jawa melalui metode SAS Struktural Analitik Sintetik. Subyek penelitian adalah siswa kelas V SD Negeri 2 Kaligondang dengan jumlah 23 siswa. Penelitian ini merupakan Penelitian Tindakan Kelas (PTK) dilaksanakan dalam 2 siklus. Setiap siklus terdiri dari 2 kali pertemuan, setiap pertemuan 2 jam pelajaran. Prosedur pelaksanaan setiap siklus meliputi perencanaan, pelaksanaan tindakan, observasi, dan refleksi. Pengumpulan data diperoleh dari lembar observasi guru dan siswa. Untuk data hasil rasa ingin tahu dan prestasi belajar siswa diperoleh dari hasil tes evaluasi dan angket di setiap akhir siklus. Adapun hasil siklus I menghasilkan data untuk rasa ingin tahu dan prestasi belajar sebagai berikut: Rasa ingin tahu siswa rata-ratanya 28,51. Ketuntasan belajar pada siklus I sebesar 60,86\% menghasilkan rata-rata 68,65. Hasil pada siklus II menghasilkan data untuk rasa ingin tahu dan prestasi belajar siswa sebagai berikut: Rasa ingin tahu siswa rataratanya 34,13. Ketuntasan belajar pada siklus II sebesar 86,95 \% menghasilkan rata-rata 80,47. Dengan demikian, dapat disimpulkan bahwa metode Struktural Analitik Sintetik dapat meningkatkan rasa ingin tahu dan prestasi belajar Bahasa Jawa siswa kelas V SD Negeri 2 Kaligondang.

Kata kunci : rasa ingin tahu, prestasi belajar, bahasa jawa, metode sas (struktural analitik sintetik).

\section{PENDAHULUAN}

Pendidikan merupakan bagian yang tidak terpisahkan dari kemajuan, perkembangan suatu bangsa dan negara. Perubahan zaman menuju era globalisasi yang menuntut segalanya lebih maju dan cepat, diupayakan ilmu pengetahuan dan teknologi dapat membantu dalam melestarikan budaya jawa. Pendidikan merupakan satu langkah kongkret dalam upaya melestarikan keanekaragaman budaya yang ada di Indonesia, melalui pendidikan generasi muda sebagai generasi penerus bangsa sebaiknya mulai diperkenalan dengan kebudayaan yang ada di tiap-tiap daerah. Pendidikan merupakan 
salah satu cara untuk mendapatkan pengetahuan yang baru. Orang yang awalnya tidak tahu menjadi tahu, yang tadinya tidak bisa menjadi bisa, yang semula tidak mengerti menjadi mengerti, hal tersebut dapat diperoleh melalui pendidikan.

Mata pelajaran Bahasa Jawa merupakan mata pelajaran yang sulit untuk dipelajari, karena siswa mengangga materi menulis aksara jawa rumit untuk dipelajari materi yang mempunyai berbagai macam bentuk dan pasangannya. Guru sebagai tenaga pendidik di sekolah dituntut untuk membangkitkan rasa ingin tahu siswa, dengan adanya rasa ingin tahu pada diri siswa dapat memudahkan membimbing dan mengarahkan siswa untuk belajar Bahsa Jawa materi menulis aksara jawa. Cara membangkitkan rasa ingin tahu dengan menggunakan metode pembelajaran yang melibatkan siswa secara aktif dalam proses pembelajaran. Rasa bosan dan jenuh pada saat proses pembelajaran dapat dihindari dan rasa senang untuk belajar akan muncul dalam benak pikiran siswa. Rasa senang akan mendorong siswa untuk berusaha mengetahui atau mencari tahu hal-hal yang belum diketahuinya.

Rasa ingin tahu siswa yang rendah mengakibatkan nilai belajar siswa juga rendah. Berdasarkan nilai ulangan harian Bahasa Jawa semester II tahun 2013/2014, dari 18 siswa dengan rincian 8 laki-laki dan 10 perempuan. Terdapat 12 siswa yang mendapatkan nilai berada dibawah KKM yaitu 65 , dari hasil tersebut $66,66 \%$ siswa dinyatakan belum tuntas pada materi menulis aksara jawa. Hasil nilai belajar dan pelaksanaan pembelajaran mata pelajaran Bahasa Jawa dari uraian di atas perlu diupayakan untuk meningkatkan rasa ingin tahu siswa pada mata pelajaran Bahasa Jawa, dan prestasi belajar siswa pada materi menulis aksara jawa. Berdasarkan hasil diskusi peneliti dengan guru kelas, untuk memecahkan

masalah

tersebut

menggunakan metode SAS.

Metode SAS yaitu metode yang digunakan untuk membaca menulis permulaan di SD, dalam proses pembelajaran metode SAS mempunyai langkah-langkah dengan urutan: Struktur menampilkan keseluruhan; Analitik melakukan proses penguraian; Sintetik melakukan penggabungan kembali kepada bentuk Struktural semula. Langkah-langkah pembelajaran metode SAS melibatkan siswa secara aktif dalam proses pembelajarannya, siswa akan merasa senang tidak jenuh. Siswa mempunyai dorongan, ketertarikan dan hasrat untuk belajar Bahasa Jawa materi menulis aksara jawa. Rasa ingin tahu muncul jika siswa tertaarik pada sesuatu hal dan mempunyai dorongan untuk belajar.

Tujuan umum dari penelitian ini adalah untuk meningkatkan kualitas pembelajaran Bahasa Jawa di Sekolah Dasar, untuk mengubah interaksi antara guru dengan siswa dalam upaya menumbuhkan aktivitas siswa dalam belajar, meningkatkan prestasi belajar dan mengatasi kendala yang dihadapi guru pada saat berlangsung proses belajar mengajar. Sedangkan tujuan khususnya adalah untuk meningkatkan prestasi belajar Bahasa Jawa materi menulis aksara jawa melalui penerapan metode SAS (Struktural Analitik Sintetik) di kelas V SD Negeri 2 Kaligondang.

\section{TINJAUAN PUSTAKA}

Pendidikan karakter adalah karakter diartikan sebagai sifat manusia pada umumnya yang bergantung pada faktor kehidupannya sendiri. Karakter adalah sifat kewajiban, akhlak, atau budi pekerti yang menjadi ciri khas seseorang atau sekelompok orang. Karakter merupakan nilai-nilai perilaku manusia yang berhubungan dengan Tuhan Yang maha 
Esa, diri sendiri, sesama manusia, lingkungan, dan kebangsaan, yang terwujud dalam pikiran, sikap, perasaan, perkataan, dan perbuatan berdasarkan norma-norma agama, hukum, tata karma, budaya, dan adat istiadat. (Fitri, 2012:20).

Samani (2012: 52) menyatakan bahwa pendidikan karakter pada intinya bertujuan membentuk bangsa yang tangguh, kompetitif, berakhlak mulia, bermoral, bertoleran, bergotong royong, berjiwa politik, berkembang dinamis, berorientasi ilmu pengetahuan dan tekhnologi yang semuanya dijiwai oleh iman dan takwa kepada Tuhan Yang Maha Esa berdasarkan Pancasila.

Menurut Hadi dan Permata (2010: 3) ingin tahu adalah suatu dorongan atau hasrat. Untuk lebih mengerti suatu hal yang sebelumnya kurang atau tidak kita ketahui. Rasa Ingin Tahu biasanya berkembang apabila melihat keadaan diri sendiri atau melihat keadaan sekelilingnya yang lebih menarik.

Rasa ingin tahu yang kuat merupakan motivasi kaum ilmuwan. Dalam sifatnya yang bersifat heran dan kagum, rasa ingin tahu telah membuat manusia ingin menjadi ahli dalam suatu bidang pengetahuan. Rasa ingin tahu ini membuat bekerjanya kedua jenis otak, yaitu otak kiri dan otak kanan,yang satu adalah kemampuan untuk memahami dan mengantisipasi informasi, sedang yang lain adalah menguatkannya dan mengencangkan memori jangka panjang untuk informasi baru yang mengejutkan (Mustari, 2011:105).

Winkel (1996: 226) mengemukakan bahwa prestasi belajar merupakan bukti keberhasilan yang telah dicapai oleh seseorang. Prestasi belajar merupakan hasil maksimum yang dicapai oleh seseorang setelah melaksanakan usaha-usaha belajar. Arifin (2011:12) menyebutkan prestasi belajar pada umumnya berkenaan dengan aspek pengetahuan, sedangkan hasil belajar meliputi aspek pembentukan watak peserta didik. Kata prestasi banyak digunakan dalam berbagai bidang dan kegiatan antara lain dalam kesenian, olahraga, dan pendidikan, khususnya pembelajaran. Prestasi belajar merupakan suatu masalah yang bersifat perennial dalam sejarah kehidupan manusia, karena sepanjang rentang kehidupannya manusia selalu mengejar prestasi menurut bidang dan kemampuan masing-masing.

Tarigan, (1994: 3-4) Menulis merupakan suatu keterampilan berbahasa yang dipergunakan untuk berkomunikasi secara tidak langsung, tidak secara tatap muka dengan orang lain. Menulis ialah menurunkan atau melukiskan lambanglambang grafik yang menggambarkan suatu bahasa yang dipahami oleh seseorang, sehingga orang-orang lain dapat membaca lambang-lambang grafik tersebut apabila mereka memahami bahasa dan gambar grafik itu. Menulis merupakan suatu kegiatan yang produktif dan ekspresif.

Darusuprapta, dkk (1996: menyatakan Bahasa Jawa adalah salah satu bahasa daerah yang merupakan bagian dari kebudayaan nasional Indonesia, yang hidup dan tetap dipergunakan dalam masyarakat bahasa yang bersangkutan. Ada dua aspek dalam bahasa Jawa, yaitu sastra Jawa dan aksara Jawa. Aksara Jawa adalah carakan atau huruf yang mempunyai bentuk, tanda grafis, sistem, dan tatanan penulisan yang digunakan untuk bahasa dan sastra Jawa dalam perkembangan sejarahnya. (Dewan bahasa Jawa provinsi Jawa Tengah, 2012: 5). Aksara Jawa merupakan salah satu peninggalan budaya luhur bangsa Indonesia yang tak ternilai harganya dan mendapat pengakuan resmi dari UNESCO. Bentuk aksara jawa memiliki seni yang berbeda- 
beda sehingga menjadi peninggalan yang harus dijaga dan dilestarikan.

Metode SAS yaitu metode yang disediakan untuk belajar membaca dan menulis permulaan di kelas permulaan SD dalam proses operasionalnya, metode SAS mempunyai langkah-langkah berlandaskan operasional dengan urutan: Struktur menampilkan keseluruhan; Analitik melakukan proses penguraian; Sintetik melakukan penggabungan kembali kepada bentuk Struktural semula. Metode SAS berlandaskan beberapa prinsip, yaitu prinsip linguistik (ilmu bahasa) yang memandang satuan bahasa terkecil untuk berkomunikasi adalah kalimat. Kalimat dibentuk oleh satuan-satuan bahasa di bawahnya yakni kata, suku kata dan fonem (huruf-huruf). Metode SAS juga mempertimbangkan pengalaman bahasa anak. Oleh karena itu, pelajaran akan lebih bermakna karena bertolak dari sesuatu yang dikenal dan diketahui anak (Setyani, 2012).

Diah (2012) metode SAS adalah metode khusus yang disediakan untuk belajar membaca dan menulis permulaan di $\mathrm{SD}$, dimana dalam proses operasional dibagi menjadi 3 tahap yaitu proses struktural (menampilkan keseluruhan), proses analitis (proses penguraian), dan proses penggabungan kembali untuk struktural.

\section{METODOLOGI PENELITIAN}

Penelitian tindakan kelas yang terdiri dari empat tahap yaitu perencanaan (planning), pelaksanaan (acting), pengamatan (observing), refleksi (reflection), dilaksanakan secara kolaboratif. Teknik pengumpulan data menggunakan teknik tes dan non tes, teknik tes berupa tes kognitif dalam bentuk uraian yang terdiri dari 10 soal. Teknik non tes berupa lembar observasi guru, siswa dan angket rasa ingin tahu siswa.

Penelitian tindakan kelas ini dilaksanakaan pada tanggal 13-22 April 2015 di kelas V SD Negeri 2 Kaligondang Kecamatan Kaligondang, Kabupaten Purbalingga. Jumlah siswa 23 dengan rincian 12 siswa laki-laki dan 11 siswa perempuan.

Metode pengumpulan data yang digunakan dalam penelitian ini adalah sebagai berikut:

Tes sebagai alat penilaian adalah pertanyaan-pertanyaan yang diberikan kepada siswa untuk mendapat jawaban dari siswa dalam bentuk lisan (tes lisan), dalam bentuk tulisan (tes tulisan), atau dalam bentuk perbuatan (tes tindakan).Tes pada umumnya digunakan untuk menilai dan mengukur hasil belajar siswa, terutama hasil belajar kognitif berkenaan dengan penguasaan bahan pengajaran sesuai dengan tujuan pendidikan dan pengajaran (Sudjana, 2010:35). Sukamadinata (2010: 321) adalah cara-cara mengumpulkan data dengan menggunakan alat atau instrumen yang bersifat mengukur, seperti tes kecerdasan, tes bakat, tes minat, tes kepribadian, tes hasil belajar.

Observasi merupakan alat penilaian yang banyak digunakan untuk mengukur tingkah laku individu ataupun proses terjadinya suatu kegiatan yang dapat diamati, baik dalam situasi yang sebenarnya maupun dalam situasi buatan. Dengan kata lain, observasi dapat mengukur atau menilai hasil dan proses belajar misalnya tingkah laku siswa pada waktu belajar, tingkah laku guru pada waktu mengajar, kegiatan diskusi siswa, partisipasi siswa dalam kegiatan simulasi, dan penggunaan alat peraga pada waktu mengajar (Sudjana, 2010:84).

Angket termasuk alat mengumpulkan dan mencatat data atau informasi, pendapat, dan paham dalam hubungan klausal.Angket mempunyai kesamaan dengan wawancara, kecuali dalam implementasinya angket dilakukan secara tertulis, sedangkan wawancara 
dilakukan secara lisan (Arifin, 2011:166).

Penelitian ini dianggap berhasil atau dihentikan diukur berdasarkan sebagai berikut: sekurang-kurangnya $85 \%$ jumlah siswa telah mencapai sikap rasa ingin tahu dengan kriteria sangat baik dan adanya ketuntasan belajar siswa, yaitu apabila nilai individu memenuhi $\mathrm{KKM} \geq$ 65dengan presentase klasikal lebih dari atau sama dengan $85 \%$.

\section{HASIL DAN PEMBAHASAN}

Rekapitulai angket rasa ingin tahu siswa dapat dilihat pada tabel 1 .

Tabel 1 Hasil Angket Rasa Ingin Tahu Siswa Siklus I dan II

\begin{tabular}{|r|l|c|c|}
\hline No & \multicolumn{1}{|c|}{ Pencapaian respon siswa } & Siklus I & Siklus II \\
\hline 1. & Rata-rata & 28,51 & 34,13 \\
\hline 2. & Persentase & $71,41 \%$ & $85,43 \%$ \\
\hline
\end{tabular}

Dari tabel dan gambar di atas dapat dilihat peningkatan rasa ingin tahu pada pembelajaran Bahasa Jawa, materi menulis aksara jawa menggunakan metode SAS.
Siklus I memperoleh nilai rata-rata 28,51 dengan ketuntasan $71,41 \%$. Siklus II meningkat rata-rata 34,13 , dengan ketuntasan 85,43\%.

Tabel 2 Peningkatan Prestasi belajar Siswa Siklus I dan II

\begin{tabular}{|l|c|c|}
\hline \multicolumn{1}{|c|}{ Indikator } & Siklus I & Siklus II \\
\hline Siswa tuntas & 14 & 20 \\
\hline Siswa tidak tuntas & 9 & 3 \\
\hline Nilai tertinggi & 100 & 100 \\
\hline Nilai terendah & 35 & 52 \\
\hline Rata-rata & 68,65 & 80,47 \\
\hline Persentase ketuntasan & $60,86 \%$ & $86,95 \%$ \\
\hline
\end{tabular}

Tabel 2 peningkatan prestasi belajar siswa dilihat bahwa menunjukkan peningkatan hasil prestasi belajar dari siklus I dan II. Pada siklus I siswa masih belum dapat memahami pembelajaran dengan baik, karena siswa baru mengenal pembelajaran menggunakan metode SAS

Siswa yang tidak paham ketika mengurai kalimat menjadi per-suku kata. Hal itu berpengaruh terhadap nilai yang diperoleh siswa, pada siklus II nilai siswa meningkat karena siswa mulai terbiasa belajar menggunakan metode SAS. Siswa memperhatikan guru pada saat guru memberikan contoh mengurai kata atau kalimat menjadi per-suku kata. Siklus I terdapat 9 siswa yang belum tuntas, ratarata 68,65 dan pada siklus II meningkat rata-rata menjadi 80,47 . Dari hasil tersebut siswa telah mencapai indikator keberhasilan $\geq 85 \%$. Guru sangat berpengaruh terhadap ketuntasan nilai siswa, karena dalam proses pembelajarannya guru menggunakan metode SAS. Langkah-langkah pembelajaran metode SAS yang sistematis dan runtut, mengambil kata atau kalimat dari kesimpulasn cerita kemudian diuraikan menjadi per-suku kata atau huruf, selanjutnya menggabungkan kembali ke kalimat utuh. Proses pembelajaran seperti itu memudahkan siswa untuk menulis aksara jawa, karena menulis aksara jawa berbeda dengan menulis latin. Menulis aksara jawa terdapat dua suku kata, sehingga metode SAS sangat tepat untuk pembelajaran Bahasa Jawa materi menulis aksara jawa.

Berdasarkan hasil penelitian yang telah diuraikan dapat disimpulkan bahwa 
pembelajaran menggunakan metode SAS dapat meningkatkan rasa ingin tahu dan prestasi belajar siswa pada mata pelajaran Bahasa Jawa materi menulis aksara jawa.

\section{SIMPULAN DAN SARAN}

Berdasarkan hasil dari penelitian yang telah dilakukan di kelas V SD Negeri 2 Kaligondang melalui 2 siklus pada mata pelajaran Bahasa Jawa materi menulis aksara jawa sebagai berikut ini : Metode SAS dapat meningkatkan prestasi belajar siswa. Hal ini dibuktikan dengan nilai ratarata prestasi belajar siswa mengalami peningkatan dari siklus I yaitu 68,65 , ketuntasan $60,86 \%$. Pada siklus II rata-rata meningkat menjadi 80,47, ketuntasan $86,95 \%$. Metode SAS dapat meningkatkan rasa ingin tahu siswa. Hal ini dibuktikan dengan perolehan rata-rata angket rasa ingin tahu siswa mengalami peningkatan dari angket rasa ingin tahu siswa mengalami peningkatan dari rata-rata 28,51, ketuntasan 71,41\%. Pada siklus II meningkat rata-rata menjadi 34,13, ketuntasan $85,43 \%$.

Berdasarkan kesimpulan di atas, terdapat beberapa hal yang harus diperhatikan guru untuk meningkatkan rasa ingin tahu dan prestasi belajar siswa pada saat proses pembelajaran. peneliti memberikan beberapa saran sebagai berikut: Pada saat menggunakan metode SAS dalam proses pembelajaran guru harus melibatkan siswa secara aktif. Dengan cara melakukan tanya jawab antara guru dan siswa, sehingga guru dapat mengetahui seberapa besar rasa ingin tahu siswa terhadap mata pelajaran Bahasa Jawa materi menulis aksara jawa. Selain itu guru juga dapat mengukur kemampuan siswa dalam memahami materi yang sudah diajarkan. Metode SAS memerlukan waktu dan kegiatan yang cukup lama, guru harus bisa memanfaatkan waktu sebaik mungkin dikarenakan minimnya alokasi waktu untuk pelajaran Bahasa Jawa. Dengan cara guru harus bisa mengkondisikan kelas supaya dalam proses pembelajaran, sesuai dengan rencana pelaksanaan pembelajaran yang telah dibuat. Dalam membacakan cerita guru harus melibatkan siswa, sehingga pada saat guru sedang membacakan cerita siswa tidak merasa jenuh dan mengantuk. Guru memahami langkah-langkah metode SAS, khususnya pada saat penguraian kata atau kalimat mmenjadi per-suku kata atau huruf, karena proes inilah yang sangat berpengaruh terhadap pemahaman siswa.

\section{DAFTAR PUSTAKA}

Arikunto, Suharsimi. 2010. Dasar-dasar Evaluasi Pendidikan. Jakarta: PT BumiAksara.

Darusuprata, dkk. 1996. Pedoman Penulisan Aksara Jawa. Yogyakarta: Yayasan Pustaka Nusantara.

Diah dan Setyani. 2012. Metode Pembelajaran Struktural Analitik Sintetik. [Online]

diakses tanggal 2 Februari 2015 Pukul 13.09

Djamarah, SB dan A.Zain. 2010. Strategi Belajar Mengajar. Jakarta: PT. Rineka Cipta.

Fitri, A.Z. 2012. Pendidikan Karakter Berbasis Nilai Etika Di Sekolah. Yogyakarta: Ar-Ruzz Media.

Kemmis dan Mc.Taggart. 1982. The Action Research Planner. Victoria: Deakin University.

Mustari, M. 2011. Nilai Karakter Refleksi Untuk Pendidikan Karakter. Yogyakarta: Laksbang Pressindo.

Tarigan, H.G. 1994. Menulis Sebagai Sebuah Keterampilan Berbahasa. Bandung:Angkas.

Trianto. 2010. Mendesain Model

Pembelajaran Inovatif-Progresif. Jakarta: Kencana 